\title{
VADOSE ZONE MEASUREMENT AND MODELING
}

\author{
J. W. HOPMANS'; V. CLAUSNITZER'; KI. KOSUGI'; D.R. NIELSEN'; F. SOMMA' \\ 'Hydrology Program, University of Califormia, Davis, CA 95616, USA. \\ ${ }^{2}$ Department of Forest, Kyoto University, Kyoto 60601, Japan.
}

\begin{abstract}
The following treatise is a summary of some of the ongoing research activities in the soil physics program at the Universtty of Califomin in Davis. Bach of the four listed areas will be presented at the Workshop on special topics on soll physics and crop modeling in Piracicaba at the University of Sao Panlo. We limted ourselves to a general overview of each area, but will present a more thorough discussion wth examples at the Workshop.

Key Words: unsaturated zone, water flow, transport processes, modeling
\end{abstract}

\section{MENSURAÇŌES E MODELAGEM NA ZONA NĀO SATURADA}

RESUMO: O presente terto é o resumo das atuals atividades do programa de fisica do solo na Universidade da Callfomia, em Davis. As quatro dreas aqui relacionadas serbo apresentadas no "Workhop on speclal topics about soll physics and crop modeling and stmulation" na Universidade de Să Paulo, em Piracicaba. $O$ terto se restringe a uma abordagem geral de cada área, porém discussões e exemplos mais detalhados serăo apresentados no Workshop.

Descritores: zona năo saturada, Iuxo de d́gua, processos de transporte, modelagem

\section{INVERSE MODELING APPROACH FOR \\ PARAMETER ESTIMATION OF SOIL WATER FLOW AND TRANSPORT PROCESSES}

As the concern for a save environment and groundwater quality increases, the importance of an accurate soil physical description of the combined unsaturatedsaturated porous system is increasingly recognized in the fields of environmental engineering and groundwater hydrology. Moreover, accurate soil physical data is required for increasingly available agrohydrological simulation models, and in the modeling of land surface processes to simulate the exchange of sensible and latent heat between the soil and atmosphere. With this wider interest, also the spatial scale of interest has shifted to larger dimensions. Soil hydraulic and transport characterization is needed for soil-water systems with the areal extend of a watershed or larger, and for depths extending from the rooting zone to the groundwater. This trend in increasing larger spatial scales of the vadose zone brings along with it the presence of increasing soil heterogeneity within the considered system. Therefore, methodologies need to be developed that allow for a rapid and accurate characterization of the soil physical properties and its spatial variability.

Currently, many laboratory and field methods exist to determine the highly nonlinear soil hydraulic functions, represented by the soil water retention and unsaturated hydraulic conductivity curves. Most methods require restrictive initial and boundary conditions, which make measurements time-consuming, rangerestricting and expensive. Excellent reviews have been published by Klute and Dirksen (1986), Klute (1986), and Green et al. (1986). Dirksen (1991) discusses the application of parameter estimation by the inverse solution technique as a viable alternative to other traditional laboratory methods for soil hydraulic characterization. The speed at which results for a large series of soil samples can be simultaneously obtained (e.g. multiplexing) and recent developments in improved methodology ' (TDR and pressure sensors) make this technique a viable alternative, especially since a single experiment yields estimates of the soil water retention and unsaturated hydraulic conductivity functions simultaneously.

The inverse problem of parameter identification for distributed numerical models has been applied in groundwater hydrology and field petroleum engineering since the early 
seventies. An excellent review of developments so far and of the state-of-the art of the inverse problem as a parameter identification procedure in groundwater hydrology was given by Yeh (1986). Its application to the vadose zone started later, and has been limited to parameter estimation of soil hydraulic properties. The parameter estimation technique as defined in this study involves the indirect estimation of soil hydraulic functions by repeated numerical solution of the governing flow equation. In this procedure, for example, soil hydraulic properties are assumed to be described by an analytical model with yet unknown parameter values. An experiment is setup under controlled conditions with prescribed initial and boundary conditions. During the experiment one or more flowcontrolled variables are measured. Subsequently, the Richards equation is solved numerically using the parameterized hydraulic functions with initial estimates for their parameters. These parameters are optimized by minimization of an objective function containing the sums of squared deviations between observed and predicted flow variables, using repeated numerical simulation of the flow process. This iterative inversion of the flow equation is in contrast to direct inversion techniques as used in analytical solutions (Yeh, 1986).

Among the first to suggest the application of computer models to estimate soil hydraulic parameters were Whisler and Watson (1968) who report on estimating the saturated conductivity of a draining soil by matching observed and simulated drainage. The pressure plate outflow method was introduced by Gardner (1956), in which an initially saturated soil was subjected to a series of step increases in air pressure with the drainage or outflow measured after each pressure step increase. Given specific assumptions, the analytical solution yields the soil diffusivity as a function of water content. Doering (1965) improved the outflow method by proposing a one-step experiment, so that considerable time-savings was achieved without loss in accuracy. Other modifications were introduced more recently by Valiantzas \& Kerkides (1990), who extended the outflow method to the simultaneous determination of soil water retention and unsaturated hydraulic conductivity using the Brooks \& Corey (1966) formulation of the soil hydraulic properties.
Although the application of the inverse approach to the outflow method appeared promising, problems have been encountered with the non-uniqueness of the optimized parameters, and associated with that the choice of the parametric form of the soil hydraulic functions to be used in the parameter optimization procedure (Russo et al., 1991). Non-uniqueness leads to more than one set of parameters, yielding minimum values for the objective function determined by local minima or by the same global minimum at more than one point in the parameter space (Carrera and Neuman, 1986b). Therefore, studies on the application of the inverse method have reported on the type of flow variable(s) to be included in the objective function.

In a numerical study, Kool et al. (1985a) were the first to apply the inverse approach by numerical solution of the Richards equation for the transient one-step outflow process. They concluded that uniqueness problems are minimized if the experiment is designed to cover a wide range in water content. Moreover, they also determined that initial parameter values must be reasonably close to their true values, and that outflow measurement errors must be small. Parker et al. (1985) subsequently experimentally applied the one-tep method to four different soils of distinct texture, and concluded that $\theta(\mathrm{h})$, the soil water retention function, and $\mathrm{K}(\theta)$, the unsaturated hydraulic conductivity function, can be optimized simultaneously by using cumulative outflow as a function of time, supplemented with the final cumulative outflow. It was also found that the optimized soil hydraulic functions could be extrapolated to a water content range beyond that achieved with the single pressure step by including an independently measured point of the soil water retention curve in the objective function. The advantage of including tensiometric data, simultaneously with the outflow measurements in the inverse approach was discussed by Kool and Parker (1988) in a hypothetical infiltration and redistribution experiment. The benefit is also intuitively clear, as the optimized soil water retention curve is forced to match observed $\theta(h)$-data. In addition, the analysis of the objective function by Toorman et al. (1992) indicated that uniqueness problems were minimized if soil water pressure head data were included in the objective function of a 
transient one-tep outflow experiment. To circumvent the need for additional soil water pressure measurements in the outflow experiment, van Dam et al. (1994) conducted outflow experiments in which the pneumatic pressure was increased in several smaller steps. Their work for a loam soil showed that the outflow data of a multi-step experiment contain sufficient information for unique estimates of the soil hydraulic functions. The experimental work by Eching \& Hopmans (1993) and Eching et al. (1994) showed how the multi-step method in combination with automated soil water pressure measurements during drainage of the soil core resuited in unique parameter values for the optimized soil hydraulic functions for four different textured soils. In their analysis an excellent match between optimized and independently measured soil water retention and unsaturated hydraulic conductivity data was found.

Russo (1988) studied the influence of the parametric form of the soil hydraulic functions on the one-step outflow optimization. For that purpose he investigated the Mualem-van Genuchten (Van Genuchten, 1980), Brooks \& Corey (1966), and the Gardner-Russo (Russo, 1988) soil hydraulic models, thereby using the data from Kool et al. (1985a). Russo (1988) concluded that the Mualem-van Genuchten model was the most accurate and the most consistent with respect to the measured data. However, in a subsequent paper, Russo et al. (1991) also pointed out that the larger number of parameters in the van Genuchten model may enhance the likelihood of non-uniqueness and instability in the inverse solution.

The most recent applications of the parameter optimization approach for the estimation of soil hydraulic properties include two-dimensional hypothetical experiments and flow simulations. For example, Simunek \& van Genuchten (1996) demonstrated that tension disc permeameter experiments complemented with soil metric potential data guaranty numerical convergence and uniqueness of the optimized parameters. Gribb (1996) used hypothetical infiltration data from a modified conepenetrometer to indirectly estimate the soil hydraulic functions. The cone-shaped device included a porous filter near the cone through which water was injected in the unsaturated soil, and two tensiometer rings, 5 and $10 \mathrm{~cm}$ above the filter. As the volume of infiltrated water is monitored, the soil water metric potential response is measured by the two tensiometer rings. The results of Gribb's (1996) parameter sensitivity analysis indicated that uncertainties with regard to the identifibility of the hydraulic parameters may occur. However, it was pointed out that real experimental data for a variety of soils and metric potential measurement locations are needed to provide a more thorough evaluation.

In solving the Richards equation, the unsaturated hydraulic properties are defined by (van Genuchten, 1980):

$$
\begin{gathered}
S_{.}=\frac{\theta(\mathrm{h})-\theta_{\mathrm{r}}}{\theta_{s}-\theta_{\mathrm{s}}}=\frac{1}{\left(1+|\alpha \mathrm{h}|^{\mathrm{n}}\right)^{\mathrm{m}}} \\
K(\theta)=K_{s} S_{e} \frac{1}{2}\left[1-\left(1-S_{e} \frac{1}{m}\right)^{m}\right]^{2}(\mathrm{~h}<0) \\
\mathrm{K}(\theta)=\mathrm{K}_{s} \quad(\mathrm{~h} \geq 0)
\end{gathered}
$$

In expressions (1) through (3), Se is the effective saturation; $\left(\theta_{\mathrm{r}}\right.$ and $\theta_{3}$ denote the residual and saturated volumetric water contents, respectively; $a$ and $n(m=1-1 / n)$ are empirical parameters; and $K_{8}$, is a fitted saturated hydraulic conductivity, not necessarily equivalent to an independently measured saturated hydraulic conductivity.

Parameters in Equations (1) through (3) are estimated from maximization of the $\mathrm{log}$ likelihood function (Bard, 1974), which includes differences between observed and predicted flow variables. Assuming measurement errors to be independent with zero mean, the parameter optimization procedure is equivalent to minimization of a weighted least squares problem, which is cast in an objective function, OF (b), with b denoting the vector containing the optimized parameters:

$$
O F(b)=\sum_{j=1}^{\infty}\left(w_{1} \sum_{i=1}^{-1} w_{i, j}\left[q_{j}^{\cdot}\left(t_{1}\right)-q_{j}\left(t_{1}, b\right)\right]^{2}\right)
$$

where $j$ represents the different sets of measurements (cumulating extraction volume, metric potential head at different locations or 
water volume in flow domain), $n_{j}$ is the number of measurements within a particular set, $\mathrm{q}_{\mathrm{*}}^{*}\left(\mathrm{t}_{\mathrm{i}}\right)$ are measurements of type $j$ at time $t_{i}, q_{i}\left(t_{i}, b\right)$ are the corresponding model predictions using the parameters in $b$, and $w_{j}$ and $w_{i j}$, are weighting factors associated with data type and data point, respectively. Differences in weighting between data types as caused by differences in magnitudes are minimized by division of each data point by the variance of the measurements of data type $j$ (Clausnitzer \& Hopmans, 1994). Thus, OF(b) is equal to the weighted average squared deviation between simulated and measured flow variables. An effective method to minimize Equation (4) was proposed by Marquardt (1963), and applies a combination of the Newton and steepest descent method. Details of this procedure can be found in Kool et al. (1987) and Simunek \& van Genuchten (1996). It here suffices to state that the Levenberg-Marquardt method is a standard method in nonlinear least squares fitting, which in addition to the sum of squared residuals of Equation (4) also provides confidence intervals for the optimized parameters.

The illposedness of an inverse solution is generally characterized by the non-uniqueness and instability of the identified parameters (Yeh, 1986). Whereas the instability stems from the fact that small errors in the measured variable may result in large changes of the optimized parameters.

Although the sensitivity of the solution to local minima will depend on the optimization algorithm, there is no guaranty to date that any available optimization code will always find the global minimum. Second, non-uniqueness is caused by a lack of sensitivity of the flow variables in the $\mathrm{OF}$ to certain parameter combinations. Sensitivity can be influenced by the type and number of optimized parameters, by model and input measurement errors, and by data type. Therefore, an experiment must be designed such that direct information is available for the least sensitive parameters, thereby eliminating them from the optimized parameter set or providing good initial well-constrained estimates. Moreover, choice of data type and their measurement in space and time should be based on a sensitivity analysis as well, so that sensitivity to the optimized parameters is maximum (Simunek \& van Genuchten, 1996). A review on illposedness and error analysis of the optimized parameters can be found in Kool \& Parker (1988), Yeh (1986), and Carrera \& Neuman (1986a,b).

We will present various applications of the parameter optimization procedure to estimate the soil hydraulic functions (1) through (3). These include the multistep outflow method, an in situ soil solution extraction technique, and an example showing that parameter optimization can be used to infer capillary pressure and permeability functions in multiphase soil systems. Moreover, using the multistepoutflow method we estimate the soil hydraulic functions using the statistical moments of the pore size distribution according to the retention model of Kosugi (1996).

\section{REFERENCES}

BARD, Y. Nonlinear parameter estimation, 341p., Academic, San Diego, California, 1974.

BROOKS, R.H; COREY, A.T. Properties of porous media affecting fluid flow. Joumal of Irrigation Drainge. Division of American Society Civi Engineering, v.92, p.61-88, 1966.

CARRERA, J.; NEUMANN, S.P. Estimation of aquifer parameters under transient and steady state conditions.]. Maximum likelihood method incorporating prior information. Water Resources Research, v.22, p.199-210, 1986a.

CARRERA, J.; NEUMANN, S.P. Estimation of aquifer parameters under transient and steady state conditions. 2. Uniqueness, stability, and solution algorithms. Water Resources Reaearch, v.22, p.211-227, $1986 \mathrm{~b}$.

CLAUSNITZER, V.; HOPMANS, J.W. Non-linear Parameter Estimation: LM_OPT.General-Purpose optimization code based on the Levenberg-Marqurdt algorithm. Land, Air and Water Resources, Paper No. 100032. University of California, Davis, CA 95616, 1995.

DIRKSEN, C. Unsaturated hydraulic conductivity. IN: SMITH, K.A; MULLINS, C.E.. Soll analysis: physical methods. New York: Marcel Dekker, 1991. p.209-269.

DOERING, E.J. Soil water diffusivity by the one-step method. Soll Science, n.99, p.322-326, 1965.

ECHING, s.O.; HOPMANS, J.W. Optimization of hydraulic functions from transient outflow and soil water pressure data. Soll Science Society of America Journal, v.57, n.5,p.1167-1175, 1993. 
ECHING, S.O.; HOPMANS, J.W.; WENDROTH, 0. Unsaturated hydraulic conductivity from transient multi-step outflow and soil water pressure data. Soll sclence Society of America Joumal, v.58, p.687-695, 1994.

GARDNER, W.R. Calculation of capillary conductivity from pressure plate outflow data. Soll Science Society of America Proceedings, v.20, p.317-320, 1956.

GREEN, R.E.; AHIA, L.R.; CHONG, S.K. In: Hydraulic conductivity, diffusivity, and sorptivity of unsaturated soils: field methods, Methods of Soil Analysis, Part I, Monograph number 9 (A. KLUTE, ed.), 1986.

GRIBB, M.M. Parameter estimation for determining hydraulic properties of a fine sand from transient flow measurements. Water Resources Research, v.32, n.7, p.1965-1974, 1996.

KLUTE, A Water retention: Laboratory methods. IN: A Klute (ed.). Methods of soil analysis. Part 1. 2nd ed. Agronomy Monograph 9:635-662. ASA and SSSA, Madision, WI. 1986.

KLUTE, A; DIRKSEN, C. Conductivities and diffusivities of unsaturated soils. IN: A. KLUTE (ed.). Methods of soil analysis. Part 1. 2nd ed. Agronomy Monograph 9:687-734. ASA and SSSA, Madision, WI. 1986.

KOOL, J.B.; PARKER, J.C.; VAN GENUCHTEN, M.Th. Determining soil hydraulic properties for one-step outflow experiments by parameter estimation. I. Theory and numerical studies. Soll science Society of America Jourmal, v.49, p.1348-1354, 1985a.

KOOL, J.B., PARKER, J.C. Estimating soil hydraulic functions from transient flow experiments: SFIT User's Guide. Soil and Environmental Sciences, Virginia Polytechnic Institute and State University, Blacksburg. VA. 1987.

KOOL, J.B.; PARKER, J.C.; VAN GENUCHTEN, M.Th. Parameter estimation for unsaturated flow and transport models - A review. Journal of Hydrology, v.91, p.255-293, 1987.

KOOL, J.B.; PARKER, J.C. Analysis of the inverse problem for transient unsaturated flow. Water Resources Research, v.24, n.6, p.817-830, 1988.

KOSUGI, K. Lognormal distribution model for unsaturated soil hydraulic properties. Water Resources Research, v.32, n.9, p.2697-2703, 1996.

MARQUARDT, D.W. An algorithm for least-squares estimation of nonlinear parameters. SIAM Joumal of Applied Mathematics, v.11, p.431-441, 1963.
PARKER, J.C.; KOOL, J.B.; VAN GENUCHTEN, M.Th. Determining soil hydraulic properties from one-step outflow experiments by parameter estimation. II. Experimental studies. Soil Science Society of America Journal, v.49, p.1354-1359, 1985.-

RUSSO, D. Determining soil hydraulic properties by parameter estimation: On the selection of a model for the hydraulic properties. Water Resources Research, v.24, p.453-459, 1988.

RUSSO, D.; BRESLER, E.; SHANI, U.; PARKER, J.C. Analysis of infiltration events in relation to determining soil hydraulic properties by inverse problem methodology. Water Resources Research, v.27, p.361-1373, 1991.

SIMUNEK, J.; SENA, M; VAN GENUCHTEN, M.Th. The HYDRUS-2D software package for simulating water flow and solute transport in two-dimensional variably saturated media. Version 1.0. IGWMC-TPS53. International Ground Water Modeling Center, Colorado School of Mines, Golden, Co. 1996.

SIMUNEK, J.; VAN GENUCHTEN, M. Th. Estimating unsaturated soil hydraulic properties from tension disc infiltrometer data by numerical inversion. Water Resources Research, v.32,n.9, p.2683-2696, 1996.

TOORMAN, AF.; WIERENGA, P.J.; HILLS, R.G. Parameter estimation of soil hydraulic properties from one-step outflow data. Water Resources Research, v.28, p.3021-3028, 1992.

VALIANTZAS, J.D.; KERKIDES, D.G. A simple iterative method for the simultaneous determination of soil hydraulic properties from one-step outflow data. Water Resources Research, v.26, p.143-152, 1990.

VAN DAM, J.C.; STRICKER, J.N.M.; DROOGERS, P Inverse method for determining soil hydraulic functions from multi-step outflow experiments. Soil Sclence Soclety of America Journal, v.58, p.647-652, 1994.

VAN GENUCHTEN, M.Th. A closed-form equation for predicting the hydraulic conductivity of unsaturated soils. Soll Science Society of America Journal, v.44,p.892-898, 1980.

WHISLER, F.D.; WATSON, K.K. One-dimensional gravity drainage of uniform columns of porous materials. Journal of Hydrology, v.6, p.277-296, 1968.

YEH, W.G. Review of parameter identification procedures in groundwater hydrology: The inverse problem. Water Resources Research, v.22, n.2, p.95-108, 1986. 